\title{
Effect of Copper, Zinc, Cadmium and Chromium in the Growth of Crambe
}

\author{
Gilvanise Alves Tito' ${ }^{1}$ Lúcia Helena Garófalo Chaves ${ }^{1}$, Josely Dantas Fernandes², \\ Danilo Rodrigues Monteiro' ${ }^{1}$, Ana Carolina Feitosa de Vasconcelos ${ }^{1}$ \\ ${ }^{1}$ Department of Agricultural Engineering, Federal University of Campina Grande (DEAG/UFCG), \\ Campina Grande, Brazil \\ ${ }^{2}$ Center of Agricultural and Environmental Sciences, State University of Paraiba, \\ Lagoa Seca, Brazil \\ Email: gilvanisetito@yahoo.com.br, Ihgarofalo@hotmail.com,joselysolo@yahoo.com.br, \\ danilor.monteiro1@gmail.com, ana3carol@yahoo.com.br
}

Received 9 July 2014; revised 15 August 2014; accepted 13 September 2014

Copyright (C) 2014 by authors and Scientific Research Publishing Inc.

This work is licensed under the Creative Commons Attribution International License (CC BY). http://creativecommons.org/licenses/by/4.0/

c) (i) Open Access

\begin{abstract}
Crambe is a promising crop for biodiesel production. However, there is no much information available about techniques and research regarding the best performance in different regions to explore its potential. The objective of this study was to evaluate the effect of cadmium, chromium, copper and zinc in the development of crambe. The study was carried out in a greenhouse and it consisted of four independent experiments in completely randomized design, with three replications. Four metals with five levels were applied: 0, 10, 15, 20 and $25 \mathrm{mg} \cdot \mathrm{kg}^{-1}$ for copper, cadmium, chromium; and $0,20,30,40$ and $50 \mathrm{mg} \cdot \mathrm{kg}^{-1}$ for zinc, in order to evaluate the growth of crambe. Data were subjected to analysis of variance and comparison of means by Tukey test at 1 and $5 \%$ significance. Despite doses of cadmium, chromium, copper and zinc in growing crambe have influenced in some of the evaluated variables of the plants, in general, their development was similar in relation to doses and the metals applied. The importance of cultivating crambe is related to grain production, based on this, copper and cadmium decreased this production.
\end{abstract}

\section{Keywords}

Heavy Metals, Biodiesel, Oleaginous

\section{Introduction}

Crambe (Crambe abyssinica H.), an oil plant of the cruciferous family, is native of the Mediterranean region

How to cite this paper: Tito, G.A., Chaves, L.H.G., Fernandes, J.D., Monteiro, D.R. and de Vasconcelos, A.C.F. (2014) Effect of Copper, Zinc, Cadmium and Chromium in the Growth of Crambe. Agricultural Sciences, 5, 975-983.

http://dx.doi.org/10.4236/as.2014.511105 
from Ethiopia to Tanzania, however, it is cultivated in tropical and subtropical regions. Crambe is characterized by being a shrubby plant, short cycle, which blooms once in 35 days and can be harvested between 90 and 95 days with uniform ripening, presenting good production. According to [1], crambe, planted in the "off-season" is an excellent alternative to crop rotation, because it has short cycle, great drought tolerance, hardiness, earliness and mechanized farming, by using the same equipment used for traditional crops grain, maximizing the use of machinery and equipment.

The crambe plant is considered robust, and develops in antagonistic weather conditions, has great tolerance to drought and frost [2]. Contrasting with climate rusticity, crambe is demanding in soil fertility, does not tolerate soil acidity, presenting the best productions in eutrophic soil [3]. According to [4], crambe takes the residual fertilizer left by summer crops, and may increase production with moderate fertilization although there are still no specific recommendations for the crop.

In recent years, this crop has become increasingly important in Brazil because of its suitability for industrial production of biofuels [5], because of its high potential lubricant and oil content. The percentage of the total oil in grains is up to $38 \%$, varying between $30 \%$ and $45 \%$ depending on climatic and soil conditions [6]. Thus, the use of crambe for the production of cleaner fuels means an important alternative to supplement energy sources more sustainable and less polluting. Moreover, crambe oil cannot be used for human consumption due to the presence of high levels of erucic acid, a monounsaturated long chain fatty acid [7].

Most heavy metals are essential to human beings, animals and higher plants, for example, $\mathrm{Co}, \mathrm{Cu}, \mathrm{Mn}, \mathrm{Zn}, \mathrm{Ni}$, among others, except $\mathrm{Cd}, \mathrm{Hg}$ and $\mathrm{Pb}$. These metals tend to be present in higher concentrations in the upper soil layers, which are a reflection of the addition of the element via atmospheric deposition, application of phosphate fertilizers, humus and also the incorporation of plants used as accumulators of metals [8]. The availability of the heavy metals for plants is governed by several soil factors such as $\mathrm{pH}$, cation exchange capacity, organic matter content, adsorption by clays and phosphorus, calcium and the presence of other metals in the soil system [9].

In general, the plants readily absorb small concentrations of $\mathrm{Cd}, \mathrm{Cr}, \mathrm{Cu}$ and $\mathrm{Zn}$ dissolved in soil solution in ionic or chelated form, or in the form of complexes; [10]. The transport of cadmium from roots to leaves is directly proportional to the external concentration of this element. However, the translocation of cadmium from leaves to fruit is low and [11] showed that the cadmium was concentrated more in roots than aerial parts of species such as soybean, carrots, alfalfa, corn and tomato. The absorption and translocation of chromium are very low, although this varies according to the species considered. Because of their affinity for negative charges, chromium is immobilized, mainly in the roots and not on the root surface. The chromium levels in the shoots are therefore very low $\left(0.02\right.$ to $\left.1 \mathrm{mg} \cdot \mathrm{kg}^{-1}\right)$ and rise only slightly when symptoms of toxicity appear [12].

Copper is absorbed in ionic form and high concentrations of phosphorus, molybdenum and zinc decrease the process that is considered active; translocation occurs within the plants in both the xylem and phloem, which is surrounded by the metal organic nitrogen compounds such as amino acids [13]. Copper is a relatively immobile element in plants. Thus, green leaves can accumulate high concentrations of copper and subsequently not release it to younger leaves and other tissues, such as inflorescences [13]. Some researchers agree with the idea that root uptake of $\mathrm{Zn}$ is active, while in the roots about $90 \%$ of $\mathrm{Zn}$ occur in the exchange sites or absorbed into the walls of the cortical parenchyma cells.

The mobility of zinc in plants is not large. Normally, the roots contain much more zinc than the shoot, especially if the plants are growing in soils rich in zinc [14] [10]. These metals can express their polluting potential directly on soil organisms, by the availability to plants in phytotoxic levels, besides the possibility of transfer into the food chain through plants themselves or the contamination of surface and subsurface water [15] [16].

Due to the growing interest in the cultivation of crambe in Brazil for biodiesel production, the objective of this work is to evaluate the effect of cadmium, chromium, copper and zinc in the development of crambe.

\section{Materials and Methods}

The study was carried out from August to November 2012 at the Agricultural Engineering Department of the Federal University of Campina Grande, Campina Grande, Paraíba, Brazil. Temperatures ranged from approximately $32^{\circ} \mathrm{C}$ during the day to $27^{\circ} \mathrm{C}$ during the night. The pluviometric precipitation was around $700 \mathrm{~mm}$ annually.

Each experimental unit consisted of a plastic pot filled with $9.0 \mathrm{~kg}$ of a Eutrofic Regosol with the following attributes: sand $=845.6 \mathrm{~g} \cdot \mathrm{kg}^{-1}$; silt $=47.2 \mathrm{~g} \cdot \mathrm{kg}^{-1}$; clay $=107.2 \mathrm{~g} \cdot \mathrm{kg}^{-1} ; \mathrm{pH}\left(\mathrm{H}_{2} \mathrm{O}\right)=5.0 ; \mathrm{Ca}^{2+}=0.51 \mathrm{cmol}_{\mathrm{c}} \cdot \mathrm{kg}^{-1}$; 
$\mathrm{Mg}^{2+}=0.20 \mathrm{cmol}_{\mathrm{c}} \cdot \mathrm{kg}^{-1} ; \mathrm{Na}=0.05 \mathrm{cmol}_{\mathrm{c}} \cdot \mathrm{kg}^{-1} ; \mathrm{K}^{+}=0.18 \mathrm{cmol}_{\mathrm{c}} \cdot \mathrm{kg}^{-1} ; \mathrm{H}^{+}+\mathrm{Al}^{3+}=0.56 \mathrm{cmol}_{\mathrm{c}} \cdot \mathrm{kg}^{-1}$; organic matter $=0.2 \mathrm{~g} \cdot \mathrm{kg}^{-1} ; \mathrm{P}=5.4 \mathrm{mg} \cdot \mathrm{kg}^{-1}$. The analyses procedures used were those recommended by [17].

The research consisted of four independent experiments, following a completely randomized design to evaluate the performance of four metals (zinc $-\mathrm{Zn}$; Copper $-\mathrm{Cu}$, cadmium- $\mathrm{Cd}$, and chromium- $\mathrm{Cr}$ ) in five doses, with three replications, totaling 15 experimental units for each metal. The solutions of $\mathrm{Zn}, \mathrm{Cu}, \mathrm{Cd}$ and $\mathrm{Cr}$ used as pollutant sources were prepared at concentrations of $0 ; 10 ; 15 ; 20: 25 \mathrm{mg} \cdot \mathrm{kg}^{-1}$ for $\mathrm{Cu}, \mathrm{Cd}$ and $\mathrm{Cr}$. For $\mathrm{Zn}$, de concentrations were $0 ; 20 ; 30 ; 40$ and $50 \mathrm{mg} \cdot \mathrm{kg}^{-1}$. All the solutions were made from Tritisol standard $1000 \mathrm{ppm}$ solution of each metal.

Each experimental unit was fertilized with $10 \mathrm{~g}$ of NPK (15:9:20) containing $166.7 \mathrm{mg} \mathrm{N} \cdot \mathrm{kg}^{-1}, 100 \mathrm{mg} \mathrm{P}_{2} \mathrm{O}_{5}$ $\mathrm{kg}^{-1}$ and $22.2 \mathrm{mg} \mathrm{K}_{2} \mathrm{O} \mathrm{kg}^{-1}$. Then, each pot was irrigated with solutions of $\mathrm{Cu}$, $\mathrm{Cd}$, $\mathrm{Cr}$ and $\mathrm{Zn}$, according to the treatment, and distilled water in order to retain the moisture corresponding to $80 \%$ of field capacity. In order to provide an opportunity to the soil interact with the metal added, the experimental units remained incubated for 8 days under the same conditions.

Crambe seedlings were prepared in plastic cups with a capacity of $250 \mathrm{ml}$ with substrate for plants using seeds without pericarp. After 8 days after germination (DAG), the seedlings were transplanted to the pots. Ten days after transplanting, the seedlings were harvested and only two plants per pot remained. They were irrigated daily in order to keep the moisture close to field capacity.

Plant height was measured with a graduated ruler, the stem diameter was measured with a digital caliper, and the counting of branches was done at 90 DAG. At the end of the experiment, during the harvest, 100 DAG, the plants were harvested, separated into leaves, stems and roots, washed in water and dried in an oven with forced air circulation at $65^{\circ} \mathrm{C}$ until constant weight. The variables evaluated were: plant height, stem diameter, number of branches, dry weight of stem, leaves, shoot and root, root/shoot ratio and grain weight.

The results were analyzed statistically through the analyses of variance (ANOVA) described by [18].

\section{Results and Discussion}

Table 1 presents the results of analysis of variance of plant height (PH), number of branches (NB), dry weight of leaves (DWL), dry weight of stems (DWSt), dry weight of shoots (DWSh), dry weight of roots (DWR), ratio of root weight by shoot weight (RW/SW) and dry weight of grains (DWG) as a function of doses of cadmium, chromium, copper and zinc. Increasing levels of metals significantly influenced the level of $5 \%$ the number of branches and dry weight of grains for cadmium; dry weight of leaves for chromium; plant height, number of branches and dry weight of grains for copper. For zinc, it was significant at $1 \%$ in number of branches. The growing importance of crambe is related to the production of grains. Based on this, it can be verified in Table 1 that only $\mathrm{Cd}$ and $\mathrm{Cu}$ presented a significant effect for the variable dry weight of grains.

The coefficients of variation (Table 1) found in this study ranged from $5.53 \%$ to $9.60 \%$, meaning homogeneity and low dispersion between the data. For most variables the coefficients of variation ranged from 10.54 to $19.98 \%$ which means average dispersion among the data. The coefficients of greater than $20 \%$ and less than or equal to $30 \%$ range are considered high, indicating high dispersion of data; and above $30 \%$, which is the case in root dry weights for all elements variable, are considered too high, according to the proposal by [18]. This very high dispersion of data roots may be due to the difficulty of recovering all the roots of the plant, since they had very thin and fragile, causing loss of material during washing.

Increased doses of $\mathrm{Cd}$ in the soil caused a decrease in the number of branches of plants and the dry weight of the grain (Figure 1). Regarding to the foliage, it was observed that the leaves became large and thick and stunted branches of crop, promoting greater dry weight of leaves. Probably because of this, the number of branches decreased and the grain formation was inhibited or promoted stunted grain, reducing the weight in relation to the increasing levels of $\mathrm{Cd}$.

In plants, the presence of Cd affects absorption, transport and use of macronutrients, such as calcium, phosphorus, potassium [19] [20], nitrate [21] and sulfur [22], as well as trace elements such as iron [23] and chlorine [24]. Due to these effects, the presence of Cd also affects plant growth.

In relation to chrome, only significant effect at $5 \%$ probability on the dry weight of the leaves of crambe whose data were best fitted to a quadratic model (Figure 2).

In general, the $\mathrm{Cr}$ absorbed by plants is accumulated in the roots presenting low mobility in plants. Although no determined the concentration of $\mathrm{Cr}$ in plant tissues, it can be inferred that the $\mathrm{Cr}$ accumulated in the leaves, 
Table 1. Summary of analyzes of variance for the data of plant height (PH), number of branches (NB), dry weight of leaves (DWL), dry weight of stems (DWSt), dry weight of shoots (DWSh), dry weight of roots (DWR), ratio of root weight by shoot weight (RW/SW) and dry weight of grains (DWG) as a function of doses of cadmium, chromium, copper and zinc.

\begin{tabular}{|c|c|c|c|c|c|c|c|c|c|}
\hline \multirow[b]{2}{*}{ Source } & \multirow[b]{2}{*}{ DF } & \multicolumn{8}{|c|}{ Mean squares } \\
\hline & & $\mathrm{PH}$ & NB & DWL & DWSt & DWSh & DWR & RW/SW & DWG \\
\hline \multicolumn{10}{|c|}{ Cadmium } \\
\hline LEV & 4 & $368.69^{\text {ns }}$ & $200.14^{*}$ & $1.75^{\mathrm{ns}}$ & $0.29^{\mathrm{ns}}$ & $2.47^{\mathrm{ns}}$ & $0.05^{\mathrm{ns}}$ & $0.0001^{\text {ns }}$ & $2.62^{*}$ \\
\hline Lin. & & - & $358.13^{*}$ & - & - & - & - & - & $8.81^{* *}$ \\
\hline Qua. & & - & $342.42^{*}$ & - & - & - & - & - & $0.004^{\mathrm{ns}}$ \\
\hline ERROR & 10 & 266.98 & 45.46 & 0.46 & 0.99 & 2.42 & 0.07 & 0.0002 & 0.46 \\
\hline CV (\%) & & 31.18 & 16.20 & 19.66 & 19.98 & 18.43 & 30.05 & 14.96 & 20.63 \\
\hline GM & & 52.40 & 41.63 & 3.47 & 4.98 & 8.45 & 0.91 & 0.106 & 3.30 \\
\hline \multicolumn{10}{|c|}{ Chromium } \\
\hline LEV & 4 & $18.55^{\mathrm{ns}}$ & $84.85^{\mathrm{ns}}$ & $0.74^{*}$ & $0.57^{\mathrm{ns}}$ & $2.53^{\mathrm{ns}}$ & $0.04^{\mathrm{ns}}$ & $0.0001^{\mathrm{ns}}$ & $0.29^{\mathrm{ns}}$ \\
\hline Lin. & & - & - & $0.34^{\mathrm{ns}}$ & - & - & - & - & - \\
\hline Qua. & & - & - & $2.57^{* *}$ & - & - & - & - & - \\
\hline ERROR & 10 & 35.95 & 26.81 & 0.22 & 0.62 & 1.45 & 0.05 & 0.0005 & 0.28 \\
\hline CV(\%) & & 8.81 & 11.16 & 20.38 & 19.82 & 19.14 & 37.68 & 23.84 & 11.76 \\
\hline GM & & 68.03 & 46.40 & 2.31 & 3.97 & 6.29 & 0.60 & 0.094 & 4.51 \\
\hline \multicolumn{10}{|c|}{ Copper } \\
\hline LEV & 4 & $55.85^{\text {ns }}$ & $98.01^{*}$ & $0.88^{\text {ns }}$ & $1.14^{\mathrm{ns}}$ & $3.78^{\text {ns }}$ & $0.05^{\mathrm{ns}}$ & $0.0001^{\mathrm{ns}}$ & $0.73^{*}$ \\
\hline Lin. & & $50.17^{\mathrm{ns}}$ & $342.96^{* *}$ & - & - & - & - & - & $0.59^{\mathrm{ns}}$ \\
\hline Qua. & & $1.30^{\mathrm{ns}}$ & $9.53^{\mathrm{ns}}$ & - & - & - & - & - & $2.31^{* *}$ \\
\hline ERROR & 10 & 14.25 & 22.43 & 0.26 & 0.49 & 1.29 & 0.04 & 0.0005 & 0.19 \\
\hline CV (\%) & & 5.53 & 10.03 & 23.14 & 19.01 & 19.17 & 34.84 & 22.52 & 9.60 \\
\hline GM & & 68.23 & 47.20 & 2.23 & 3.71 & 5.94 & 0.61 & 0.102 & 4.54 \\
\hline \multicolumn{10}{|c|}{ Zinc } \\
\hline LEV & 4 & $23.30^{\text {ns }}$ & $223.22^{* *}$ & $0.74^{\mathrm{ns}}$ & $0.44^{\mathrm{ns}}$ & $2.23^{\text {ns }}$ & $0.04^{\mathrm{ns}}$ & $0.0001^{\mathrm{ns}}$ & $0.05^{\mathrm{ns}}$ \\
\hline Lin. & & - & $184.06^{* *}$ & - & - & - & - & - & - \\
\hline Qua. & & - & $658.50^{* *}$ & - & - & - & - & - & - \\
\hline Cub. & & - & $14.48^{\text {ns }}$ & - & - & - & - & - & - \\
\hline ERROR & 10 & 89.66 & 16.78 & 0.37 & 0.79 & 2.11 & 0.06 & 0.0004 & 0.30 \\
\hline CV (\%) & & 14.52 & 10.11 & 26.97 & 23.13 & 23.70 & 42.59 & 23.73 & 12.09 \\
\hline GM & & 65.20 & 40.53 & 2.27 & 3.86 & 6.13 & 0.59 & 0.09 & 4.56 \\
\hline
\end{tabular}

**; * and ${ }^{\mathrm{ns}}$ : Significant at 1 and 5\% of probability, and no-significant, respectively. LEV = levels; CV = coefficient of variation; GM = general mean.

since increased levels of this element influencing their development [25]. Crambe plants grown in soil supplied, on average, with $13 \mathrm{mg} \mathrm{Cr} \mathrm{kg}^{-1}$, resulted in a $20 \%$ reduction in dry weight of leaves compared to control. Although some studies show that Cr produce some stimulatory effects on plant growth [26] [27] its essentiality has not been proven. As [28] the reduction in leaf growth of tomato plants, due to the presence of chromium, just started to occur at concentrations greater than $100 \mathrm{mg} \mathrm{Cr}^{+3} \mathrm{~L}^{-1}$.

The number of branches and the weight of the grains of crambe were influenced at $5 \%$ probability with increasing levels of copper (Table 1). The data of these variables were best fitted to models linear and quadratic, respectively (Figure 3 ).

The presence of branches is responsible for having the function of sustaining the fruits besides being a source of minerals and assimilates drain. Therefore, reducing the number of branches can increase grain yield by reducing the sap to drain them, as can be seen in Figure 3. For the dry weight of grains there was a small increase 

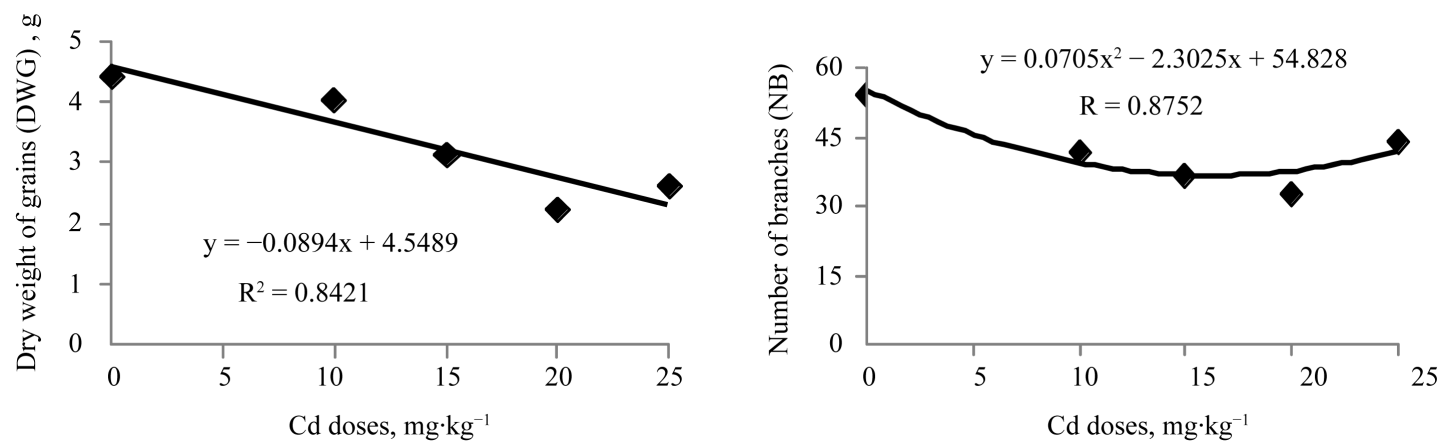

Figure 1. Dry weight of grains and number of branches of crambe according to the doses of cadmium.

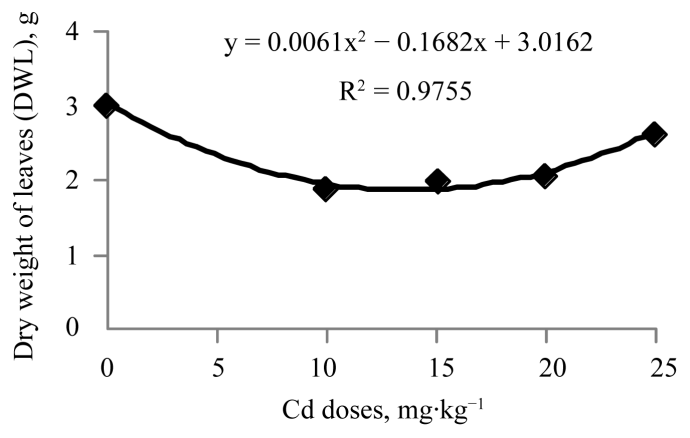

Figure 2. Dry weight of leaves of crambe according to the doses of chromium.
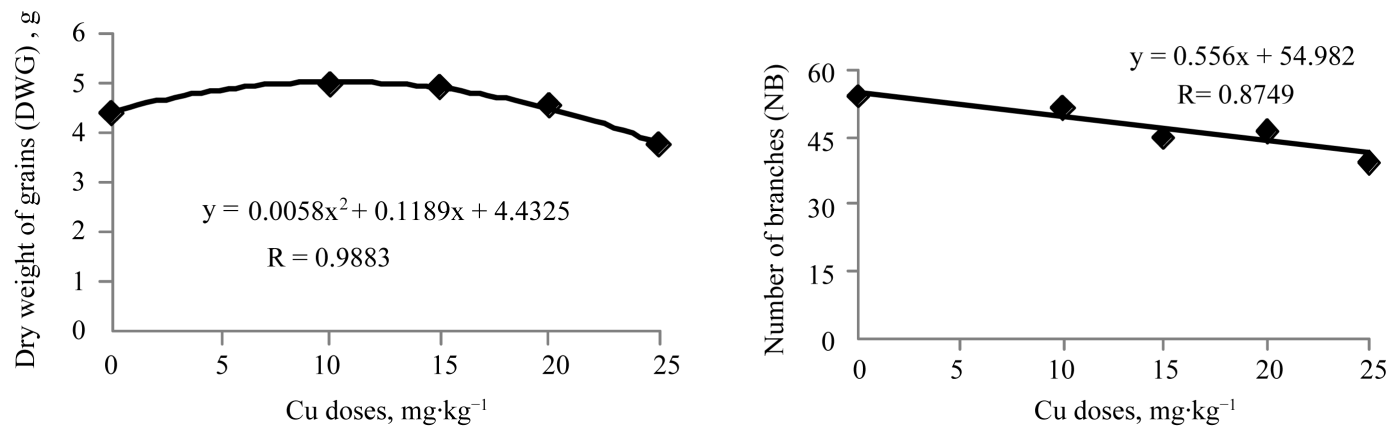

Figure 3. Dry weight of grains and number of branches of crambe according to the doses of copper.

in the first dose of $\mathrm{Cu}$ compared to the control (4.45 g per plant) decreasing with increasing doses to $3.76 \mathrm{~g}$ per plant.

Even with the aggravation of soil contamination, results are superior to those obtained by [29] evaluated the effect of base saturation in the development and yield of crambe grown in medium textured soil where found 2.22 g per plant. On the other hand [30], evaluating organic fertilization in crambe achieved a mean grain weight of $5.64 \mathrm{~g}$ per plant. Increasing levels of $\mathrm{Zn}$ influenced the $1 \%$ probability the number of branches of crambe (Table 1), whose data of this variable were best fitted the quadratic model (Figure 4). There was a tendency to decrease compared to control up to level $20 \mathrm{mg} \mathrm{Zn} \mathrm{kg}^{-1}$, returning to growth in higher levels studied, up to 50 $\mathrm{mg} \cdot \mathrm{kg}^{-1}$, reaching 44 branches. However, this number is still lower than the control (54) within the range cited by [31], in which the plant crambe has 30 or more branches.

In general, small changes in the data for plant height (from the control to highest level) were similar for all metals (Table 2). Only with the increase in cadmium levels, there was a trend to reduce plant height. However, data of crambe height, reported in Table 2, were lower than some results reported in the literature.

According to [31] the height of crambe can reach up to $100 \mathrm{~cm}$; however, [32] mentioned that the height va- 


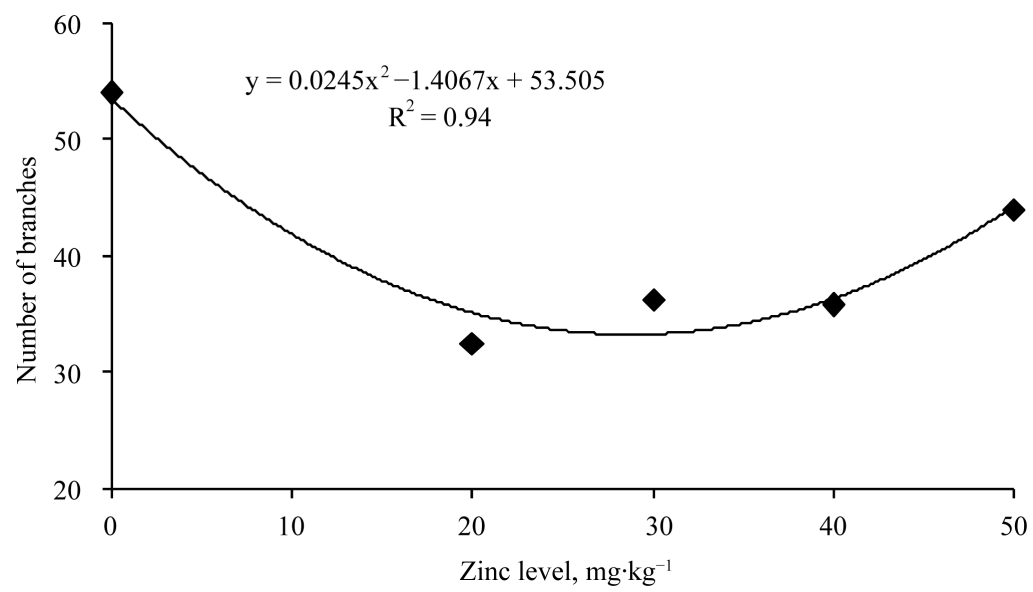

Figure 4. Number of branches according to zinc level in the planting of crambe.

Table 2. Average data of plant height (PH), stem diameter, number of branches (NB), dry weight of leaves (DWL), dry weight of stems (DWSt), dry weight of shoots (DWSh), dry weight of roots (DWR), ratio of root weight by shoot weight (RW/SW) and dry weight of grains (DWG) as a function of doses of cadmium, chromium, copper and zinc.

\begin{tabular}{|c|c|c|c|c|c|c|c|c|}
\hline Doses & $\mathrm{PH}$ & NB & DWL & DWSt & DWSh & DWR & RW/SW & DWG \\
\hline $\mathrm{mg} \cdot \mathrm{kg}^{-1}$ & $\mathrm{~cm}$ & & g/plant & g/plant & g/plant & $\mathrm{g} /$ plant & & g/plant \\
\hline \multicolumn{9}{|c|}{ Cadmium } \\
\hline 0 & 66.17 & 54.00 & 3.03 & 4.47 & 7.50 & 0.80 & 0.10 & 4.45 \\
\hline 10 & 60.00 & 41.50 & 2.88 & 5.12 & 8.01 & 0.93 & 0.11 & 4.05 \\
\hline 15 & 50.00 & 36.50 & 3.17 & 5.26 & 8.42 & 0.84 & 0.10 & 3.14 \\
\hline 20 & 37.50 & 32.50 & 4.78 & 5.16 & 9.93 & 1.14 & 0.11 & 1.63 \\
\hline 25 & 48.33 & 43.67 & 3.53 & 4.91 & 8.43 & 0.87 & 0.10 & 2.64 \\
\hline \multicolumn{9}{|c|}{ Chromium } \\
\hline 0 & 66.17 & 54.00 & 3.03 & 4.47 & 7.50 & 0.80 & 0.10 & 4.45 \\
\hline 10 & 66.50 & 42.33 & 1.86 & 3.36 & 5.22 & 0.48 & 0.09 & 4.46 \\
\hline 15 & 67.67 & 40.67 & 2.00 & 3.91 & 5.90 & 0.58 & 0.10 & 4.81 \\
\hline 20 & 72.33 & 46.17 & 2.06 & 3.82 & 5.88 & 0.58 & 0.10 & 4.05 \\
\hline 25 & 67.50 & 48.83 & 2.64 & 4.33 & 6.97 & 0.60 & 0.09 & 4.81 \\
\hline \multicolumn{9}{|c|}{ Copper } \\
\hline 0 & 66.17 & 54.00 & 3.03 & 4.47 & 7.50 & 0.80 & 0.10 & 4.45 \\
\hline 10 & 62.17 & 51.50 & 1.52 & 3.13 & 4.66 & 0.43 & 0.09 & 4.99 \\
\hline 15 & 73.00 & 44.83 & 2.30 & 4.05 & 6.35 & 0.64 & 0.10 & 4.94 \\
\hline 20 & 71.50 & 46.17 & 2.27 & 3.89 & 6.16 & 0.68 & 0.11 & 4.57 \\
\hline 25 & 68.33 & 39.50 & 2.05 & 3.02 & 5.07 & 0.54 & 0.11 & 3.76 \\
\hline \multicolumn{9}{|c|}{ Zinc } \\
\hline 0 & 66.17 & 54.00 & 3.03 & 4.47 & 7.50 & 0.80 & 0.10 & 4.45 \\
\hline 20 & 61.83 & 32.50 & 1.76 & 3.75 & 5.51 & 0.49 & 0.09 & 4.48 \\
\hline 30 & 68.00 & 36.33 & 2.48 & 4.01 & 6.49 & 0.55 & 0.08 & 4.78 \\
\hline 40 & 62.67 & 35.83 & 1.98 & 3.50 & 5.47 & 0.59 & 0.10 & 4.62 \\
\hline 50 & 67.33 & 44.00 & 2.12 & 3.62 & 5.74 & 0.54 & 0.09 & 4.48 \\
\hline
\end{tabular}


ries between 70 and $90 \mathrm{~cm}$. Almeida et al. [33] and [34] studied the cultivation of crambe in the field, under different fertilization and found the greatest heights of $123 \mathrm{~cm}$ and $109.54 \mathrm{~cm}$, respectively. Santos et al. [35] analyzed different levels of water for irrigation of crambe and observed the largest height of $107.63 \mathrm{~cm}$.

Carvalho et al. [36] found inferior results to the present study i.e., they observed $45.25 \mathrm{~cm}$ of plant height grown in the Oxisol with $75 \%$ base saturation and [37] observed $58 \mathrm{~cm}$ height plant grown for different spacing in Hapludox Haplortox.

According to [32], the height varies depending on the time of planting and plant density. In the present study, the decrease in plant height may have been due to plant fertilization, and/or the effect of metals and/or because the planting season (August to November) which is related to climate, i.e. plants were developed at a higher ambient temperature than in other traditional growing regions of crambe (April or May).

Increasing levels of metals significantly influenced the number of branches, with the exception of chromium (Table 1). The average of number of branches ranged from 40.53 for $\mathrm{Zn}$ to $47.20 \mathrm{for} \mathrm{Cu}$, values within cited by [31], in which the plants presented 30 or more branches.

The dry weight of the leaves ranged from $3.03 \mathrm{~g}$ to $2.05 \mathrm{~g}$, and $3.03 \mathrm{~g}$ to $2.12 \mathrm{~g}$, corresponding to increasing levels of $\mathrm{Cu}$ and $\mathrm{Zn}$, respectively, being not affected by application of these elements in growing crambe, corroborating [38] that analyzed increasing doses of zinc in bean plants.

The dry weight of the stems as well as the production of dry matter of shoots and roots of crambe was not affected by the application of all doses of $\mathrm{Cd}, \mathrm{Cr}, \mathrm{Cu}$ and $\mathrm{Zn}$ to the soil, whose values were statistically similar to those obtained in the absence these metals (Table 2). Tito et al. [38] analyzing increasing doses of zinc in beans, also found no significant effect on the weight of the roots. However, it had a significant effect on the dry mass of stems and grains, corroborating [39] that researched about corn, and disagreeing with [40] for the cultivation of sorghum. Regarding Cr, [41] observed that the reduction in dry matter of shoots and roots of soybeans occurred at $40 \mathrm{mg} \mathrm{Cr}^{+3} \mathrm{~L}^{-1}$. i.e. up to this dose, chromium does not affect these variables of the plant. Observing the values of the dry weight of stems, dry matter production of shoots and roots even without statistical analysis, apparently, the values corresponding to increasing levels of $\mathrm{Cd}$ were higher than with the application of $\mathrm{Cr}$, $\mathrm{Cu}$ and Zn, disagreement with [38] who observed lower biomass production of beans in the presence of Cd compared to $\mathrm{Cu}$ and $\mathrm{Zn}$.

The application of metals to soil did not affect root/shoot crambe plants ratio (Table 1), corroborating [29]. The behavior observed in this ratio with increased levels of all elements used (Table 2) may be associated with similar roots and aerial parts of the plants.

The dry weight of the grains of cultivated plants with $\mathrm{Cr}$ and $\mathrm{Zn}$ were not affected by increasing doses of these elements, corroborating [30]. These authors, applying increasing doses of poultry litter in growing crambe, no significant effect of this material on the weight of the grains was observed, that ranged from $4.77 \mathrm{~g}$ (zero $\mathrm{g}$ of poultry litter) to $6.40 \mathrm{~g}$ (140 g poultry litter).

\section{Conclusions}

Although the dosages of cadmium, chromium, copper and zinc in growing crambe have influenced in some of the variables of the plant in general, their development was similar in both in relation to doses as the metal used. Increasing levels of metals influenced significantly number of branches, with the exception of the metal chromium, which showed no significant difference.

The production of grain was harmed only with copper and cadmium in the conditions adopted for this study.

\section{Acknowledgements}

Special thanks to Coordination of Improvement of Higher Education Personnel—CAPES for the grants to the first author.

\section{References}

[1] Pitol, C., Broch, D.L. and Roscoe, R. (2010) CRAMBE: Tecnologia e Produção. Fundação Mato Grosso, Maracaju.

[2] Desai, B.B. (2004) Seeds Handbook: Biology, Production Processing and Storage. 2nd Edition, Marcel Dekker, New York.

[3] Broch, D.L., Ranno, S.K. and Roscoe, R. (2010) Efeito de Adubações de Plantio e Cobertura Sobre a Produtividade de 
Crambe cv. FMS Brilhante Após Soja e Milho. Proceedings of the 1th Congresso Brasileiro de Mamona, and Proceedings of the 4th Simpósio Internacional de Oleaginosas Energéticas, 7-10 June 2010, João Pessoa, 652-657.

[4] Roscoe, R. and Delmontes, A.M.A. (2008) Crambe é Nova Opção Para Biodiesel. Agrianual 2009. Instituto FNP, São Paulo.

[5] Teixeira, R.N., Toledo, M.Z., Ferreira, G., Cavariani, C. and Jasper, S.P. (2011) Germinação e Vigor de Sementes de Crambe sob Estresse Hídrico. Irriga, 16, 42-51.

[6] Katepa-Mupondwa, F. (1999) Developing Oilseed Yellow Mustard (Sinapis alba L.) in Western Canada. Proceeding of the 10th International and International Rapeseed Congress, 26-29 September 1999, Canberra, 55-59.

[7] Colodetti, T.V., Martins, L.D., Rodrigues, W.N., Brinate, S.V.B. and Tomaz, M.A. (2012) Crambe: Aspectos Gerais da Produção Agrícola. Enciclopédia Biosfera, Centro Científico Conhecer, 8, 258-269.

[8] McBride, M.D. (1994) Environmental Chemistry of Soils. Oxford University, New York.

[9] Macêdo, L.S. and Morril, W.B.B. (2008) Origem e Comportamento dos Metais Fitotóxicos: Revisão da Literatura. Tecnologia \& Ciência Agropecuária, 2, 29-38.

[10] Kabata-Pendias, A. and Pendias, H. (2010) Trace Elements in Soils and Plants. 3rd Edition, CRC Press, Boca Raton. http://dx.doi.org/10.1201/b10158

[11] McLean, A.J. (1976) Cadmium in Different Plant Species and Its Availability in Soils as Influenced by Organic Matter and Additions of Lime, P, Cd and Zn. Canadian Journal of Soil Science, 56, 129-138. http://dx.doi.org/10.4141/cjss76-021

[12] Bergmann, W. (1992) Nutritional Disorders of Plants: Developments, Visual and Analytical Diagnosis. Gustav Fischer Verlang Jena, New York.

[13] Baker, D.E. (1990) Copper. In: Alloway, B.J., Ed., Heavy Metals in Soils, John Wiley, New York, 151-196.

[14] Mengel, K. and Kirkby, E.A. (1982) Principles of Plant Nutrition. International Potash Institute, Worblaufen.

[15] Chang, A.C., Page, A.L., Warneke, J.E. and Grgurevic, E.S. (1987) Sequential Extraction on Soil Heavy Metals Following a Sludge Application. Journal of Environmental Quality, 13, 33-38. http://dx.doi.org/10.2134/jeq1984.00472425001300010006x

[16] Soares, C.R.F.S., Siqueira, J.O., Carvalho, J.G. and Moreira, F.M.S. (2005) Fitotoxidez de cádmio para Eucalyptus maculata e E. urophylla em solução nutritiva. Revista Árvore, 29, 175-183. http://dx.doi.org/10.1590/S0100-67622005000200001

[17] Empresa Brasileira De Pesquisa Agropecuária (Embrapa) (1997) Manual de métodos de análise de solo. Centro Nacional de Pesquisa de Solos, Rio de Janeiro.

[18] Ferreira, D.F. (2009) Estatística Básica. 2rd Edition, Ufla, Lavras.

[19] Nocito, F.F., Pirovano, L., Cocucci, M. and Sacchi, G.A. (2002) Cadmium-Induced Sulfate Uptake in Maize Roots. Plant Physiology, 129, 1872-1879. http://dx.doi.org/10.1104/pp.002659

[20] Paiva, H.N., Carvalho, J.G., Siqueira, J.O., Miranda, J.R.P. and Fernades, A.R. (2004) Absorção de nutrientes por mudas de ipe-roxo (Tabebuia impetiginosa (Mart.) Standl.) em solução nutritiva contaminada por Cádmio. Revista Árvore, 28, 189-197. http://dx.doi.org/10.1590/S0100-67622004000200005

[21] Hernandez, L.E., Carpena-Ruiz, R. and Garate, A. (1996) Alterations in the Mineral Nutrition of Pea Seedlings Exposed to Cadmium. Journal of Plant Nutrition, 19, 1581-1598. http://dx.doi.org/10.1080/01904169609365223

[22] Jiang, R.F., Ma, D.Y., Zhao, F.J. and Mcgrath, S.P. (2005) Cadmium Hyperaccumulation Protects Thlaspi caerulescens from Leaf Feeding Damage by Thrips (Frankliniella occidentalis). New Phytologist, 167, 805-814. http://dx.doi.org/10.1111/j.1469-8137.2005.01452.x

[23] Kurdziel, B.M., Prasad, M.N.V. and Strzalka, K. (2004) Photosynthesis in Heavy Metal Stressed Plants. In: Prasad, M.N.V., Ed., Heavy Metal Stress in Plants: From Biomolecules to Ecosystems, 2nd Edition, Springer-Verlag Berlin Heidelberg, 146-181.

[24] Losch, R. (2004) Plant Mitochondrial Respiration under the Influence of Heavy Metals. In: Prasad, M.N.V., Ed., Heavy Metal Stress in Plants: From Biomolecules to Ecosystems, 2nd Edition, Springer-Verlag Berlin Heidelberg, 182-200.

[25] Nogueira, T.A.R., Oliveira, L.R., Melo, W.J., Fonseca, I.M., Melo, G.M.P., Melo, V.P. and Marques, M.O. (2008) Cádmio, cromo, chumbo e zinco em plantas de milho e em latossolo após nove aplicações anuais de lodo de esgoto. Revista Brasileira de Ciência do Solo, 32, 2195-2207. http://dx.doi.org/10.1590/S0100-06832008000500040

[26] Grubinger, V.P., Gutenmann, H.W., Doss, G.J., Rutzke, M. and Lisk, D.J. (1983) Chromium in Swiss Chard Grown on Soil Amended with Tannery Meal Fertilizer. Chemosphere, 28, 717-720. http://dx.doi.org/10.1016/0045-6535(94)90223-2

[27] Marchiori Júnior, M., Melo, W.J., Bertipaglia, L.M.A. and Melo, G.M.P. (1999) Plantas de Sorgo Cultivadas sob 
Aplicação de Biossólido Contaminado com Doses Crescentes de Crômio. Proceedings of 14th Congresso Latinoamericano de La Ciencia del Suelo, Temuco, 8-12 November 1999, CDRom.

[28] Moral, R., Pedreno, N., Gomez, I. and Mataix, J. (1995) Effects of Chromium on the Nutrient Element Content and Morphology of Tomato. Journal of Plant Nutrition, 18, 815-822. http://dx.doi.org/10.1080/01904169509364940

[29] Janegitz, M.C., Souza-Schlick, G.D., Tropaldi, L. and de Moura Cardoso, S. (2010) Influência da saturação por bases no crescimento e produção de crambe. Cultivando o Saber, 3, 175-182.

[30] Frediani, F.R. and Fernandes, F.C.S. (2012) Avaliação de adubação orgânica em crambe. Cultivando o Saber, 5, 7-13.

[31] Desai, B.B., Kotecha, P.M. and Salunkhe, D.K. (1997) Seeds Handbook: Biology, Production Processing and Storage. Marcel Dekker, New York.

[32] Möller, M. (2007) Crambe, alternativa para a produção de óleo. Aracajú, MS. 40 slides. wwww.ruralsementes.com.br

[33] Almeida, D.P., Timossi, P.C., Souza, H.S., Gomes, E.L.D. and Silva, W.S. (2012) Interferência das plantas daninhas no cultivo de crambe com diferentes tipos de fertilizantes. Proceedings of the 28th Congresso Brasileiro da Ciência das Plantas Daninhas na Era Biotecnologia, Campo Grande, 3-6 September 2012, 151-155.

[34] Viana, O.H., Santos, R.F., Secco, D., Souza, S.N.M. and Cattanêo, A.J. (2012) Efeitos de diferentes doses de adubação de base no desenvolvimento e produtividade de grãos e óleo na cultura do crambe. Acta Iguazu, 1, 33-41.

[35] Santos, R.F., Fornasari, C.H., Secco, D., Souza, S.N.M., Silva, T.R.B. and Bassegio, D. (2012) Manejo de irrigação com evaporímetro em Crambe abyssinica. Acta Iguazu, 1, 23-32.

[36] Carvalho, K.S., Silva, B.E.M., Avelino, C.E., Leite, C.N. and Koetz, M. (2012) Crambe cultivado em latossolo do cerrado submetido à calagem. Enciclopédia Biosfera, Centro Científico Conhecer, 8, 552-558.

[37] Dalchiavon, M.P., Santos, R.F., Souza, S.N., Bassegio, D., Rossetto, C. and Bauermann, H.B. (2012) Comportamento de altura de plantas de Crambe abyssynica em função da variação de densidade de plantio. Acta Iguazu, 1, 33-43.

[38] Tito, G.A., Chaves, L.H.G., Guerra, H.O.C. and Soares, F.A.L. (2011) Phytomass of Beans and Grain Production as Affected by Zinc, Copper and Cadmium Doses and Bentonite Application. Revista Brasileira Engenharia Agrícola e Ambiental, 15, 665-669.

[39] Muner, L.H., Ruiz, H.A., Venegas, V.H.A., Neves, J.C.L., Freire, F.J. and Freire, M.B.G.S. (2011) Disponibilidade de zinco para milho em resposta à localização de fósforo no solo. Revista Brasileira Engenharia Agrícola e Ambiental, 15, 29-36. http://dx.doi.org/10.1590/S1415-43662011000100005

[40] Santos, H.C., Fraga, V.S., Raposo, R.W.C. and Pereira, W.E. (2009) Cu e Zn na cultura do sorgo cultivado em três classes de solos. I. Crescimento vegetativo e produção. Revista Brasileira Engenharia Agrícola e Ambiental, 13, 125130.

[41] Castilhos, D.D., Guadagnin, C.A., Silva, M.D., Leitzke, V.W., Ferreira, L.H. and Nunes, M.C. (2001) Acúmulo de cromo e seus efeitos na fixação biológica de nitrogênio e absorção de nutrientes em soja. Revista Brasileira de Agrociência, 7, 121-124. 
Scientific Research Publishing (SCIRP) is one of the largest Open Access journal publishers. It is currently publishing more than 200 open access, online, peer-reviewed journals covering a wide range of academic disciplines. SCIRP serves the worldwide academic communities and contributes to the progress and application of science with its publication.

Other selected journals from SCIRP are listed as below. Submit your manuscript to us via either submit@scirp.org or Online Submission Portal.
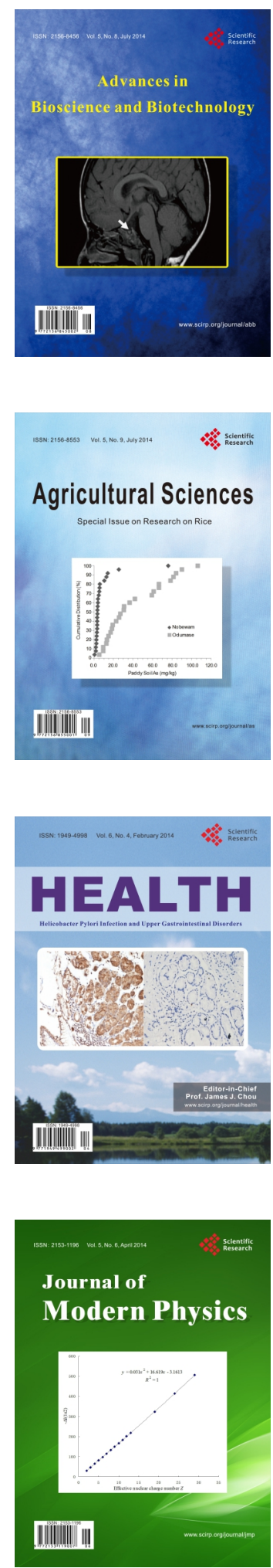
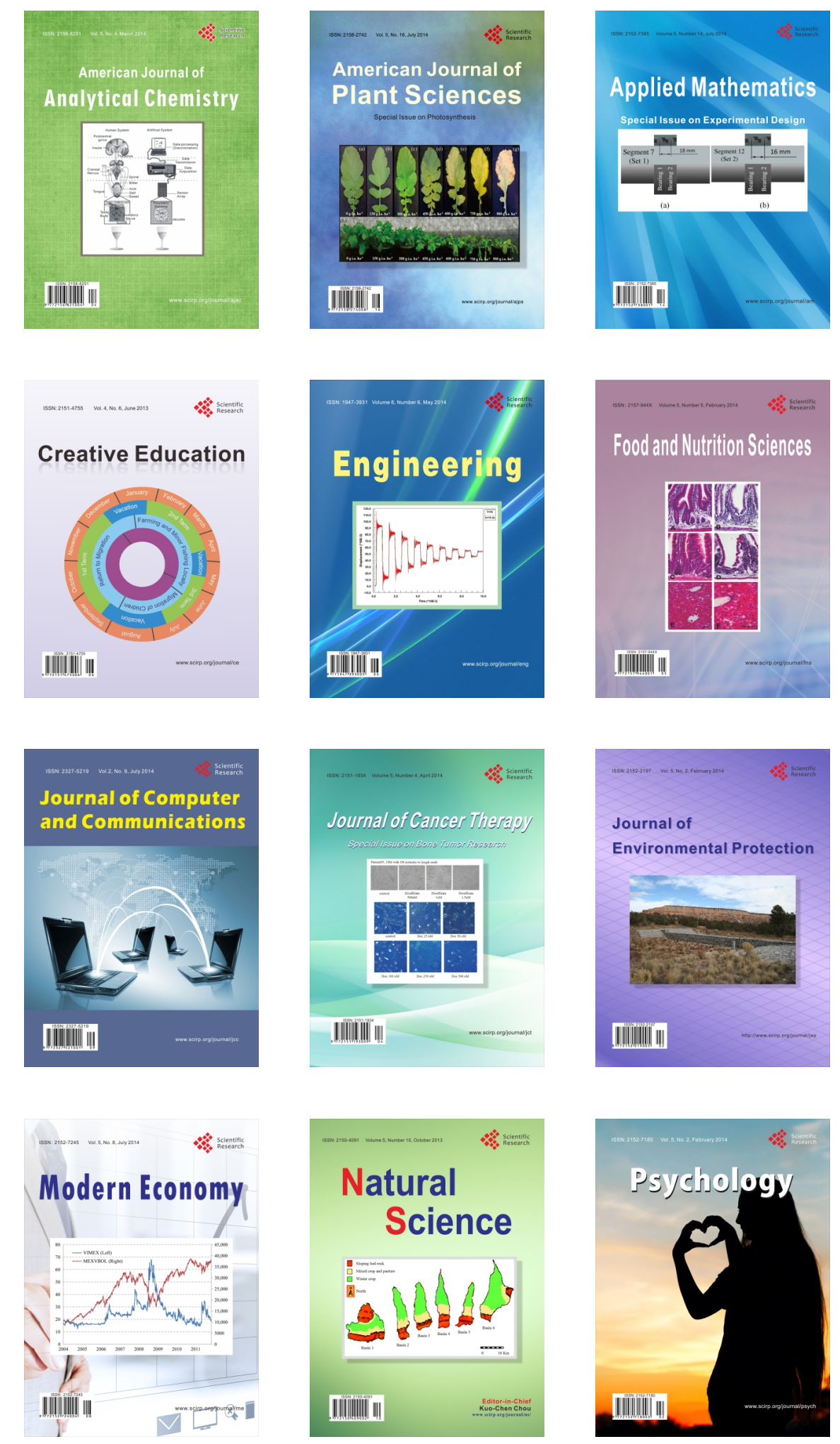